\title{
Impact of Leverage and Firm Size on Earnings Persistence with Managerial Ownership as Moderating Variables
}

\author{
Dade Nurdiniah, Chita Oktapriana, Iren Meita, and Milla Damay Yanti
}

\section{ABSTRACT}

This study aims to examine and analyze the effect of leverage and firm size on earnings persistence with managerial ownership as a moderating variable. The population in this study is manufacturing companies listed on the Indonesia Stock Exchange in 2016-2019. The sample selection method used purposive sampling criteria, while the data analysis methods used in this study were multiple regression analysis and moderated regression analysis. Before analysing the data, first perform the classical assumption test, after the data is declared to meet the test criteria, then a hypothesis test is carried out consisting of multiple regression analysis, coefficient of determination test (R-squares), simultaneous significance test (F-test), significance test partial test (t-test) and moderated regression analysis (MRA). The results showed that leverage had a positive effect on earnings persistence, and firm size had no effect on earnings persistence, while managerial ownership was unable to moderate the effect of leverage and firm size on earnings persistence.

Keywords: Earnings Persistence, Firm Size, Leverage, Managerial Ownership.

\author{
Submitted : August 31, 2021 \\ Published : September 24, 2021 \\ ISSN: 2507-1076 \\ DOI: $10.24018 / \mathrm{ejbmr} .2021 .6 .5 .1080$ \\ Dade Nurdiniah* \\ Universitas Bina Insani, West Java, \\ Indonesia. \\ (e-mail: dade@ ${ }^{\circledR i n a i n s a n i . a c . i d) ~}$ \\ Chita Oktapriana \\ Universitas Bina Insani, West Java, \\ Indonesia. \\ (e-mail: chitaoktapriana@ ${ }^{@}$ binainsani.ac.id) \\ Iren Meita \\ Universitas Bina Insani, West Java, \\ Indonesia. \\ (e-mail: Irenmeitaaa ${ }^{\circledR}$ gmail.com) \\ Milla Damay Yanti \\ Universitas Bina Insani, West Java, \\ Indonesia. \\ *Corresponding Author
}

\section{INTRODUCTION}

Companies are generally required to make financial reports as a form of management accountability to external parties for the resources that have been used, including investors in terms of making investment decisions, creditors in terms of lending funds, management in terms of giving bonuses to employees of the company. In addition, the financial statements also reflect the company's performance, which is reflected in the company's profits. Therefore, profit becomes the center of attention of users of financial statements. Profit is an important element in financial statements with indicators used to measure company performance. Profit is a measurement of changes in shareholder wealth or estimated future profits [1]. FASB defines Accounting Profit as the change in equity (net assets) of an entity during a certain period resulting from transactions and events or events that originate not from the owners. A company is considered healthy if it produces persistent profits or does not often fluctuate each period. The earnings persistence is a profit that has the ability as an indicator of future earnings generated by the company repeatedly (repetitive) in the long term (sustainable) [2]. By performing earnings persistence, the company can predict future profits by implementing current year earnings. A persistent profit is highly expected by investors because it can reduce investor anxiety about the investment decisions that have been taken.
Earning persistence activities is closely related to modifying earnings or earnings management. Earnings management can be said to be positive if it is carried out properly and does not eliminate the quality of the earnings. However, earnings management actions can be said to be negative if they are carried out excessively and are used to cover losses that should be borne. Profit modification is a common practice for companies, for example PT Bank Bukopin, Tbk (source: kontan.co.id). The banking company has made improvements to the company's financial statements for 2016 which caused quite significant changes, especially in profit. This change occurred due to an improper recording of income from the credit card business so that it did not match reality. These changes were made so that the company's financial condition that was experiencing a decline could not be seen and to reduce the risk of investors withdrawing as investors in PT Bank Bukopin, Tbk. To generate a persistent profit can be influenced by certain factors. However, in this study the factors that are thought to influence earnings persistence are the level of debt, firm size, and managerial ownership.

The first factor that is thought to influence earnings persistence is the level of debt (leverage). One of the efforts that can be made by PT Bank Bukopin, Tbk to cover these losses is by making loans or debts. Currently, loans with debt are an alternative to corporate funding. However, if the 
company's debt level is high enough, investors will be wary of continuing to invest in the company. A high level of debt is one of the factors for carrying out profit modification actions so that the company's profits look persistent or stable. The level of debt encourages companies to increase earnings persistence with the aim of maintaining good performance in the eyes of auditors and users of financial statements [3]. Good performance is expected by creditors to continue to have confidence in the company, continue to provide loans, and the company will obtain convenience in the payment process [4]. Research conducted by [3], [5]-[15] show that debt levels have a positive effect on earnings persistence. Meanwhile, research conducted by [16], [17] shows that debt levels have a negative effect on earnings persistence. Meanwhile, research conducted by [18]-[21], showed that the level of debt has no effect on earnings persistence.

Other factors besides being influenced by the level of debt, earnings persistence is also influenced by firm size. Company size is the size of the company. Large companies have better stability and predictable operations, so that the resulting estimation error will be smaller. In addition, large companies have large resources for their business activities. Large companies are considered to have good prospects in a relatively long period of time, but it also reflects that the company is relatively more stable and more able to generate profits than companies with smaller total assets. With the size of the company, of course, the higher profit growth is also expected. High profit growth is expected by investors, but it can be suspected as a practice of modifying earnings so that company profits look persistent. The persistence of high corporate earnings indicates a stronger relationship between corporate profits and returns for investors in the form of stock returns. This is what makes investors have more confidence and are more interested in large companies, because large companies are considered capable of continuously improving their company's performance by trying to increase the persistence of company profits [21]. Research conducted by [5], [6], [12], [13], [20]-[22] showed that firm size has a positive effect on earnings persistence. Meanwhile, research conducted by [14] showed that firm size has a negative effect on earnings persistence. The results of research conducted by [18]-[19], [23], [24], show that firm size does not affect on earnings persistence.

Another factor that is also thought to influence earnings persistence apart from debt level and firm size is managerial ownership. Managerial ownership is the amount of share ownership of the company's management who actively participates in making company decisions. Managerial ownership is one way to minimize agency conflict [25]. With managerial ownership, agents will be motivated to work better in improving company performance, because agents have a share in the profits generated by the company [26]. Managerial ownership can be used to determine the quality of earnings which is reflected in the persistence of earnings, the greater the management owns of the company's shares, the greater the manager's sense of responsibility to account for his financial statements [3]. Managers who are also shareholders will try to increase the persistence of company profits, because with increasing company profits, the dividends distributed to shareholders will also increase. So that the interests of managers (agents) and investors outside the company will be in line, namely to both obtain large dividends from their investment results.

The factors of debt level, firm size, and managerial ownership have been widely studied by previous researchers, but the results obtained from several studies are inconsistent. There is a significant research gap between research results. With a significant research gap between the results of one research and another and the importance of earnings persistence in Indonesia, this research is encouraged to be conducted. The difference between this research and previous research is by adding one variable, namely firm size, and moving the managerial ownership variable as a moderating variable. The moderating variable used to assess whether the influence of the dependent variable with the independent variable will be stronger or weaker. The study was conducted on manufacturing companies listed on the Indonesia Stock Exchange from 2016-2019 period.

\section{LITERATURE REVIEW}

\section{A. Theoretical Basis}

Agency theory is one of the theories that is often used as a theoretical basis in accounting research. [25] define an agency relationship as "a contract in which one or more persons (principal) engage another person (agent) to perform some services on their behalf (principal) which involves delegating authority to make some decisions to the agent". The relationship that occurs between the principal (shareholder) and the agent (company management) creates problems, namely differences in interests, and incurs costs to overcome these problems. Agency theory is closely related to earnings modification actions, especially earnings persistence, because these actions are carried out as proof that management (agents) are doing what investors (principals) want. The purpose of this action is the desire of investors in receiving dividends and management's interest in receiving stable compensation. So that profit persistence is carried out so that the interests of both parties, namely agents and management, remain in line.

Besides agency theory, another theory related to earnings modification is signal theory. Signal theory provides information to the principal regarding the condition of the company. If the information to be provided is of a bad nature, the manager must continue to report the information to maintain the credibility of the shares traded on the stock market (stock exchange). So, a logical consequence of signal theory is that there is an incentive for all managers to receive signals of the expectation of future profits. Because if investors believe in the signal, then management and principals will benefit [27]. Information published as a signal from the company must provide information or a description of the company's past, present, and future conditions. One of the information is the annual report, because the report contains information related to financial and non-financial. Profit is a component of the annual report, which is a signal from the company to external parties (creditors and investors). If the company's profits are stable or persistent, it means that the signal is a good signal.

The desire of investors to get higher returns, makes the company make profit modifications. This modification, 
action is carried out so that the profits listed in the financial statements look persistent. Persistent profit is profit that does not often fluctuate every period and tends to be stable [28]. Earnings modification, action will affect the quality of the earnings. According [29], earnings will be of good quality if they can be a good indicator of future earnings. High-quality earnings are profits that reflect sustainability or a sustainable report. Thus, unsustainable earnings (unusual earnings) can be stated that the earnings quality is poor.

Today, debt is one of the alternative funding for companies with various considerations. Among other things, financing with debt allows companies to enjoy the effects of tax deductions because interest payments are usually tax deductible [30]. Because dividends that have been paid by the company on funds that have been given by investors cannot be used as a deduction from taxable income. However, high debt levels are also a threat to the company because potential investors will be cautious when investing. Companies that have high debt levels result in a loss of investor confidence. So the company must restore this trust by showing that the company's profits are persistent [31]. Efforts made by the company are included in the act of modifying earnings. The higher the level of debt, the greater the company's efforts to improve company performance, through company profits. With better performance, it is hoped that creditors will continue to have confidence in the company so that they are given convenience in the process of borrowing funds and processing payments [32].

The size of a company will affect potential investors in investing. The size of the company is expressed in total assets, if the greater the total assets of the company, the larger the size of the company. Companies with a large number of assets indicate that the company is relatively more stable and able to generate greater profits compared to companies that have fewer total assets [23]. Basically, the size of the company is divided into three categories, namely: large companies (large firms), medium companies (medium firms), and small companies (small firms). According to Article 1 of Law No. 20 of 2008, the size of the company is divided into 4 categories, namely: Micro Enterprises, Small Businesses, Medium Enterprises and Large Enterprises. The bigger the company, the bigger the profit growth is expected. High profit growth will also affect earnings persistence and the company's sustainability in attracting potential investors who will be suspected of being a profit modification practice [12].

Managerial ownership is a situation where the manager owns the company's shares or in other words the manager does not only act as an agent but also acts as a shareholder of the company. This will make managers more active in fulfilling the wishes of shareholders who are none other than themselves. Managerial ownership can be used to determine the quality of future earnings which is reflected in the persistence of earnings, the greater the manager owns the company's shares, the greater the manager's sense of responsibility to account for the financial statements [33]. Increased managerial ownership will bring a positive response to the market. The market assumes that an increase in the proportion of managerial ownership causes the company's management to try to increase earnings persistence in order to obtain high stock returns as well.

\section{B. Hypothesis Development}

\section{1) The effect of leverage on earnings persistence}

A high level of debt is a threat to the company because investors will be vigilant and more careful in investing, so to restore the level of investor confidence, management makes performance improvements which are shown through persistent profits [31]. The greater the level of debt, the greater the company will obtain additional capital for its business activities, so that the profits generated can be maximized and persistent. Investors tend to have a better view of companies with high debt levels if the company's profits are persistent or in accordance with actual and sustainable conditions. This statement is in line with research conducted by [3], [5]-[15] which show that the level of debt has a positive effect on earnings persistence. Then research conducted by [16], [17] shows that the level of debt has a negative effect on earnings persistence. Based on this description, the formulation of the hypothesis of this study is:

\section{H1: Leverage has an effect on earnings persistence.}

\section{2) The effect of firm size on earnings persistence}

The size of a company will affect potential investors in investing. The size of the company is expressed in total assets, if the greater the total assets of the company, the larger the size of the company. Companies with a large number of assets indicate that the company is relatively more stable and able to generate greater profits compared to companies that have fewer total assets [23]. The bigger the company, the bigger the profit growth is expected. High profit growth will also affect earnings persistence and the company's sustainability in attracting potential investors who will be suspected of being a profit modification practice [12]. This statement is in line with research conducted by [5], [6], [12], [13], [20]-[22] shows that firm size has a positive effect on earnings persistence. Then research conducted by [14] shows that company size has a negative effect on earnings persistence. Based on this description, the formulation of the hypothesis of this study is:

\section{H2: Firm size has earnings persistence effect.}

\section{3) The Managerial ownership moderates the effect of leverage on earnings persistence}

Managerial ownership is a situation where the manager owns the company's shares or in other words the manager does not only act as an agent but also acts as a shareholder of the company. This will make managers more active in fulfilling the wishes of shareholders who are none other than themselves. Managerial ownership can be used to determine the quality of future earnings which is reflected in the persistence of earnings, the greater the manager's ownership the company's shares, the greater the manager's sense of responsibility to account for financial statements [3]. In the previous explanation, it is known that the greater the level of debt, the greater the company will obtain additional capital for its business activities, so that the profits generated can be maximized and persistent. Thus, companies that have large debt levels and the greater the manager's ownership company shares, the greater the manager's sense of responsibility to 
account for the financial statements, which in turn can cause company management to seek to increase earnings persistence to obtain high stock returns. Based on this description, the formulation of the hypothesis of this study is:

H3: Managerial ownership moderates the effect of leverage on earnings persistence.

\section{4) Managerial ownership moderates the effect of firm size on earnings persistence}

Managerial ownership is the ownership company shares by the commissioners or directors of the company's outstanding shares. Management not only acts as an agent, but also acts as a shareholder. This will make directors more intense in monitoring their managers, finances in order to the quality of the company and the quality of its earnings. The greater the managerial ownership, the greater the persistence of earnings. The role of managerial ownership becomes influential in the company, the manager not only acts as a manager but also as a shareholder. In the previous explanation, it is known that the larger the company, the greater the profit growth is expected. Thus, the larger the size of the company and the greater the management owns company's shares, the greater the sense of responsibility of the manager to account financial statements so that the persistence of earnings will be greater [3]. Based on this description, the formulation of the hypothesis of this study is:

H4: Managerial ownership moderates the effect of firm size on earnings persistence.

\section{Conceptual Framework}

Based on the brief explanation above, the framework of this research can be described as follows:

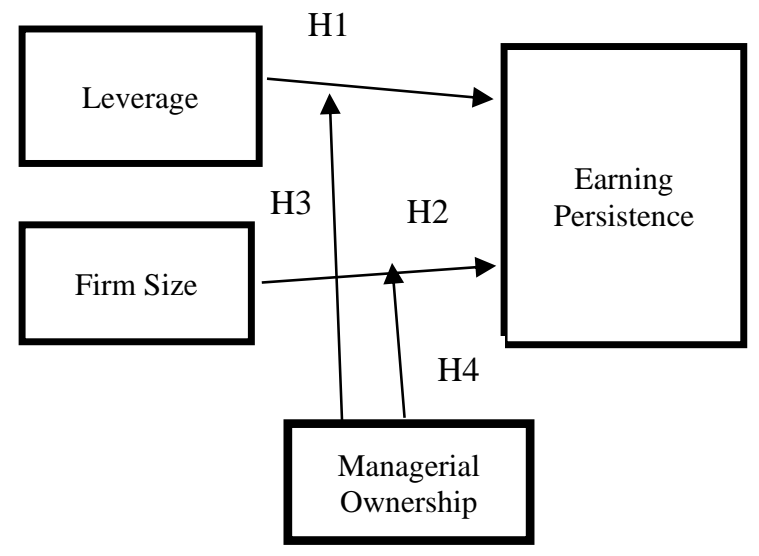

Fig. 1. Conceptual Framework

\section{RESEARCH METHODS}

\section{A. Population and Sample}

The object used in this study is a manufacturing company that has been listed on the Indonesia Stock Exchange (IDX) during 2016-2019. The population of this study are manufacturing companies that have been listed consecutively on the IDX during 2016-2019 period. The selection of this research sample is based on purposive sampling technique, so that it is based on certain criteria.

The criteria for selecting the research sample are:

1) Manufacturing companies that have been consecutively listed on the IDX for the period 2016-2019.

2) Manufacturing companies that present audited financial statements successively on the IDX during the period 2016-2019 and have a bookkeeping period as of December 31.

3) Manufacturing companies that did not suffer losses in the audited financial statements during the study period.

4) Manufacturing companies that present audited financial statements successively on the IDX during 2016-2019 period are presented in rupiah.

5) The audited financial statements must have complete information needed for this research.

\section{B. Variable Operation}

This study consists of two independent variables $(\mathrm{X})$, the dependent variable $(\mathrm{Y})$ and the moderating variable $(\mathrm{Z})$. The independent variables are leverage (X1), and firm size (X2). The dependent variable is earnings persistence, and the moderating variable is managerial ownership.

\section{1) Dependent Variable $(Y)$}

Profit is a tool to measure company performance. The desire of investors to get higher returns, makes the company make profit modifications. This modification, action is carried out so that the profits listed in the financial statements look persistent. Earning Persistent is profit that does not often fluctuate every period and tends to be stable [28]. This activity is carried out to attract investors to invest. [34] calculate earnings persistence with changes in profit before tax for the current year, which consists of profit before tax this year minus profit before tax for the previous year divided by total assets whose calculation is based on the following formula:

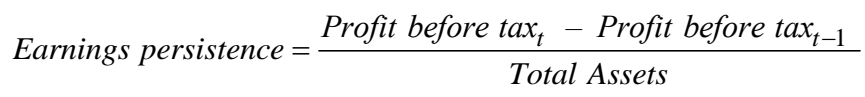

\section{2) Independent Variable $(X)$}

The independent variables or independent variables from this research are:

\section{a) Leverage (X1)}

Debt is an alternative funding for companies with various considerations. Among other things, financing with debt allows companies to enjoy the effect of tax deductions because interest payments are usually tax deductible [30]. However, high debt levels are also a threat, because potential investors will be vigilant and more careful when investing. Therefore, the company will try to improve the company's performance through company profits. Based on research conducted by [12], [14], [15], [31], the level of debt is measured by the Debt to Total Assets Ratio (DTA).

$$
\text { Debt to Total Assets }=\frac{\text { Total Debt }}{\text { Total Assets }}
$$




\section{b) Firm Size (X2)}

The size of a company will affect investors in investing. However, basically, companies are divided into three categories, namely: large companies, medium companies, and small companies. The larger the size of the company, the greater the profit growth is expected [12]. There are many measurements for company size, but based on research conducted by [12], [23], company size is measured by:

\section{Firm size $=$ Logarithm Natural Total Assets}

\section{3) Moderating Variable (Z)}

The managerial ownership is the amount of share ownership of the management and directors of the company. The existence of managerial ownership is often associated with agency theory. In agency theory, it is said that the relationship between managers and shareholders is described as the relationship between the agent and the principal. The measurement of managerial ownership variables based on research [3], [21] uses the percentage of shares obtained from the number of managerial shares divided by the total number of outstanding shares, or with the formula:

\section{Managerial Ownership $=\frac{\text { Number of managerial shares }}{\text { Number of outstanding shares }}$}

\section{Data Analysis Method}

The data analysis method used in this study is a linear regression statistical technique with hypothesis testing to analyze, test, and answer the accuracy of the hypothesis. Data processing in this study was processed with the help of EViews version 10 software. The regression equation to test the hypothesis of the impact of leverage and firm size on earnings persistence with managerial ownership as the moderating variable is as follows:

$$
\mathrm{EP}=\mathrm{a}+\beta_{1} \mathrm{Lev}+\beta_{2} \mathrm{FS}+\beta_{3} \mathrm{MO}+\beta_{4} \mathrm{Lev} * \mathrm{MO}+\beta_{5} \mathrm{FS} * \mathrm{MO}+\varepsilon
$$

$\mathrm{EP}=$ Earnings Persistence;

$\mathrm{a}=$ Constants;

Lev = Leverage;

FS = Firm Size;

MO = Managerial Ownership;

$\beta_{1}-\beta_{5}=$ Regression coefficient;

Lev*MO $=$ Interaction of leverage with Managerial Ownership;

FS*MO = Interaction of Firm Size with Managerial Ownership;

$\varepsilon=$ Error distribution.

\section{RESUlts AND Discussion}

\section{A. The Object of Study}

The focus of this study is Indonesian manufacturing companies listed on the Indonesia Stock Exchange (IDX), with the object of research in the form of annual financial reports that have been published in the IDX. The sampling technique used is a purposive sampling technique by obtaining samples that match the research criteria, so that a research sample of 42 companies is obtained for four (4) years of observation, so that this study has 168 research data, which are presented in the following table.

\begin{tabular}{clc}
\multicolumn{3}{c}{ TABLE I: RESEARCH SAMPLE DETERMINATION } \\
\hline No. & \multicolumn{1}{c}{ Description } & \multicolumn{1}{c}{ Total } \\
\hline 1. & $\begin{array}{l}\text { Manufacturing companies listed on the IDX } \\
\text { Manufacturing companies listed on the IDX in a row } \\
\text { during the 2016-2019 period } \\
\text { Companies that do not present audited financial } \\
\text { statements consecutively during the 2016-2019 } \\
\text { period and do not have a bookkeeping period as of }\end{array}$ & (42) \\
December 31 & $\begin{array}{l}\text { Manufacturing companies that suffered losses during } \\
\text { the 2016-2019 period }\end{array}$ \\
Companies that do not present audited financial \\
5.
\end{tabular}

Source: data processed by the author.

\section{B. Data Analysis}

After the research data has been processed, then data analysis is carried out. This research uses multiple regression analysis method and moderated regression analysis (MRA). Before conducting data analysis, first perform a classical assumption test, which is intended so that the resulting research data can meet the test criteria.

The classical assumption test is carried out before performing multiple analysis, regression testing and moderating regression to determine whether the moderating variable strengthens or weakens influenced the independent variable on the dependent variable, as well as a requirement to determine the feasibility of the data, so that the tested data has passed the test criteria and ensures there are no deviations for obtain accurate results with a good regression model. The classical assumption test consists of four tests, namely normality test, multicollinearity test, heteroscedasticity test, and autocorrelation test.

After testing the classical assumptions, then testing the hypothesis consisting of multiple regression analysis, coefficient of determination test (R-squares), simultaneous significance test (F-test), partial significance test (t-test) and moderated regression analysis (MRA) test.

\section{1) Multiple Regression Analysis}

The results of the calculation of Multiple Regression Analysis using EViews 10 are as shown in the following table:

TABLE II: MULTIPLE REGRESSION ANALYSIS RESULTS

\begin{tabular}{|c|c|c|c|c|}
\hline Variable & Coefficient & Std. Error & $\mathrm{t}$-Statistic & Prob. \\
\hline $\mathrm{C}$ & 0.028409 & 0.060460 & 0.469882 & 0.6391 \\
\hline LEV & 0.051338 & 0.013795 & 3.721645 & 0.0003 \\
\hline FS & -0.182815 & 0.313604 & -0.582949 & 0.5607 \\
\hline \multicolumn{5}{|c|}{ Effects Specification } \\
\hline \multirow{3}{*}{\multicolumn{3}{|c|}{$\begin{array}{l}\text { Cross-section random } \\
\text { Idiosyncratic random }\end{array}$}} & S.D. & Rho \\
\hline & & & 0.000000 & 0.0000 \\
\hline & & & 0.052779 & 1.0000 \\
\hline \multicolumn{5}{|c|}{ Weighted Statistics } \\
\hline R-squared & 0.081874 & \multicolumn{2}{|c|}{ Mean dependent var } & 0.012442 \\
\hline Adjusted R-squared & 0.065079 & \multicolumn{2}{|c|}{ S.D. dependent var } & 0.053206 \\
\hline S.E. of regression & 0.051446 & \multicolumn{2}{|c|}{ Sum squared resid } & 0.434054 \\
\hline F-statistic & 4.874909 & \multicolumn{2}{|c|}{ Durbin-Watson stat } & 2.026427 \\
\hline Prob(F-statistic) & 0.002836 & & & \\
\hline
\end{tabular}

Source: data processed by the author. 
Based on the table above, the regression model is obtained for multiple regression analysis, as follows:

$$
\mathrm{EP}=0.0284+0.0513 \mathrm{LEV}-0.1828 \mathrm{FS}+\varepsilon
$$

The conclusion can be drawn based on the above equation are as follows:

1. $\beta 0=$ constant value of 0.0284 .

This shows that if the value of leverage and firm size is zero $(0)$, then the value of earnings persistence has increased by 0.0284 .

2. $\beta 1 \mathrm{LEV}=$ regression coefficient of leverage variable of 0.0513 .

This shows that if the other independent variables have a fixed value and leverage has increased by $1 \%$, the earnings persistence value will increase by 0.0513 or $5.13 \%$.

3. $\beta 2 \mathrm{FS}=$ firm size variable regression coefficient of 0.1828 .

This shows that if the other independent variables have a fixed value and the firm size increases by $1 \%$, the earnings persistence value will decrease by 0.1828 or $18.28 \%$.

\section{2) Coefficient of Determination Test (R-squares)}

Based on the data on Table II. The value of adjusted RSquared is 0.065 . Based on these results, it can be concluded that the dependent variable, namely earning persistence, can be explained by the independent variable consisting of leverage and firm size of $6.5 \%$, while the remaining $93.5 \%$ is explained by other variables not included in this study.

\section{3) Simultaneous Significance Test (F-Test)}

Based on Table II, the Prob value (F-statistic) is 0.0028, so it is smaller than the probability value of 0.05 . Based on these results, it can be concluded that leverage, firm size, and managerial ownership, which moderate the effect of independent variables have a joint effect on earnings persistence.

\section{4) Partial Significance Test (t-test)}

The following is the effect of each independent variable based on the result of the t-test analysis:

a) Leverage

Based on Table II. Which is the result of multiple regression analysis shows that the independent variable leverage obtains a significance value of 0.0003 or is below the probability value of 0.05 . Based on these results, it can be concluded that leverage has a positive effect on earnings persistence.

\section{b) Firm Size}

In Table II. Firm size variable obtains a significance value of 0.5607 or is above, the probability value of 0.05 . Based on these results, it can be concluded that the firm's size variable has no effect on earnings persistence.

\section{5) Moderated Regression Analysis (MRA) Test}

The results of the MRA test can be seen in the Table III.

Based on the table above, the regression model for MRA analysis is obtained as follows:

$$
\begin{aligned}
\mathrm{EP}= & -0.027-0.0096 \mathrm{LEV}+0.2128 \mathrm{FS}+0.0867 \mathrm{MO}+ \\
& 0.024 \mathrm{LEV} \times \mathrm{MO}-0.4766 \mathrm{FS} \times \mathrm{MO}+\varepsilon
\end{aligned}
$$

TABLE III: MRA TEST RESULTS

\begin{tabular}{ccccc}
\multicolumn{5}{c}{ TABLE III: MRA TEST RESULTS } \\
\hline Variable & Coefficient & Std. Error & t-Statistic & Prob. \\
\hline C & -0.027061 & 0.078739 & -0.343683 & 0.7320 \\
LEV & -0.009613 & 0.037971 & -0.253155 & 0.8008 \\
FS & 0.212822 & 0.394348 & 0.539682 & 0.5909 \\
MO & 0.086695 & 0.547837 & 0.158249 & 0.8747 \\
LEV_MO & 0.024082 & 0.109558 & 0.219806 & 0.8266 \\
FS_MO & -0.476645 & 3.035743 & -0.157011 & 0.8756 \\
\hline \multicolumn{5}{c}{ Effects Specification } \\
\hline \multicolumn{5}{c}{ S.D. } \\
Cross-section random & 0.000000 & 0.0000 \\
Idiosyncratic random & 0.041950 & 1.0000 \\
\hline \multicolumn{5}{c}{ Weighted Statistics } \\
\hline R-squared & 0.005053 & Mean dependent var & 0.010885 \\
Adjusted R-squared & -0.056364 & S.D. dependent var & 0.040977 \\
S.E. of regression & 0.042116 & Sum squared resid & 0.143676 \\
F-statistic & 0.082271 & Durbin-Watson stat & 1.299150 \\
Prob(F-statistic) & 0.994823 & \\
\hline Source. data processed by the author.
\end{tabular}

The conclusion can be drawn from the above equation are:

1. $\beta 0=$ constant value of $(-0.027)$.

This shows that if the value of leverage, firm size, and managerial ownership is zero (0), then the value of earnings persistence has decreased by 0.027 .

2. $\beta 1 \mathrm{LEV}=$ the regression coefficient of the leverage variable is -0.0096 .

This shows that if the other independent variables have a fixed value and leverage has increased by $1 \%$, the earnings persistence value will decrease by 0.0096 or $0.96 \%$.

3. $\beta 2 \mathrm{FS}=$ firm size variable regression coefficient of 0.2128 .

These results indicate that if the other independent variables remain firm size increases by $1 \%$, then the earnings persistence value will increase by 0.2128 or $21.28 \%$.

4. $\beta 3 \mathrm{MO}=$ managerial ownership variable regression coefficient of 0.0867 .

This shows that if the value of other independent variables is fixed and managerial ownership has increased by $1 \%$, then the value of earnings persistence will increase by 0.0867 or $8.67 \%$.

Table III shows the interaction between leverage and managerial ownership (FS_MO) and firm size variable with managerial ownership (FS_MO), with the following interaction results:

1. The interaction between leverage and managerial ownership shows a probability value of 0.8266 or is far above, the probability value of 0.05 ( $\mathrm{P}>0.05)$, can be concluded that the interaction between leverage and managerial ownership have no effect on earnings persistence. In other words, managerial ownership is not able to moderate the effect of leverage on earnings persistence.

2. The interaction between firm size variable and managerial ownership shows a probability value of 0.8756 is above, the probability value of $0.05(\mathrm{P}>0.05)$, it can be concluded that the interaction between firm size and managerial ownership have no effect on earnings persistence. On other words, managerial ownership is not able to moderate the effect of firm size on earnings persistence.

\section{Discussion}

The following is a discussion of the results of the tests that have been carried out on the variables of leverage, firm size, and managerial ownership. 


\section{1) Leverage Effect on Earnings Persistence}

Based on the results of this study described previously, it is known that leverage has an effect on earnings persistence, which means that $\mathrm{H} 1$ is accepted. That is, the greater the debt owned by the company, the greater the profit that must be generated by the company. This conclusion is obtained from the results of multiple regression analysis, which shows a probability value of 0.0003 which is smaller than the significance value of 0.05 . This indicates that leverage is one of the factors for earnings persistence. The results of this study are consistent with research conducted by [3], [5]-[15] show that debt levels have a positive effect on earnings persistence. However, it is different from the research conducted by [18]-[21], which shows that the level of debt has no effect on earnings persistence.

\section{2) Firm Size Effect on Earnings Persistence}

Based on the results of this study described previously, it is known that firm size has no effect on earnings persistence, which means $\mathrm{H} 2$ is rejected. That is, the size of a company will not affect the decrease or increase in company profits. This conclusion is obtained from the results of multiple regression analysis, which shows a probability value of 0.5607 which is greater than a significance value of 0.05 . This indicates that firm size cannot help the company in performing earnings persistence. The results of this study are consistent with research conducted by [16]-[19], [23], [24], shows that firm size have no effect on earnings persistence. However, it is different from the research conducted by [5], [6], [12], [13], [20], [21]-[22] showed that firm size has a positive effect on earnings persistence.

\section{3) Managerial Ownership Moderates Effect of Leverage on Earnings Persistence}

Based on the results of this study described previously, it is known that managerial ownership is not able to moderate the effect of leverage on earnings persistence, which means $\mathrm{H} 3$ is rejected. It means that the size of share ownership by management in the company is not able to moderate the effect of debt levels on earnings persistence. This conclusion is obtained from the results of the interaction test which shows the probability value of $\mathrm{LEV}^{*} \mathrm{MO}$ of 0.8266 which is greater than the significance value of 0.05 . Managerial ownership is not able to moderate the effect of leverage on earnings persistence. This shows that the low share ownership by management in the company causes managers to feel that they do not have the same interests as company shareholders or other outside parties, namely obtaining high dividends from company profits with high persistence, and the high level of debt of a company will not affect the increase in company profits, because company managers tend to perform performance independent of high or low levels of debt.

\section{4) Managerial Ownership Moderates Effect of Firm Size on Earnings Persistence}

Based on the results of this study described previously, it is known that managerial ownership is not able to moderate the effect of firm size on earnings persistence, which means $\mathrm{H} 4$ is rejected. This means that the size of the share ownership by management in the company is not able to moderate the effect of company size on earnings persistence. This conclusion is obtained from the results of the interaction test which shows the FS*MO probability value of 0.8756 which is greater than the 0.05 significance value. Managerial ownership is not able to moderate the effect of firm size on earnings persistence. This shows that the size of a company will not affect the decrease or increase in company profits, and the size of the management owns the company's shares, managers will remain motivated to work better in improving company performance, because managers have a share of the profits generated by the company.

\section{CONCLUSIONS AND SUGGESTION}

\section{A. Conclusion}

Based on the results of research on the impact of leverage and firm size on earnings persistence with managerial ownership as a moderating variable, it can be concluded as follows: 1) Leverage has a positive effect on earnings persistence, 2) firm size has no effect on earnings persistence, 3) managerial ownership is not able to moderate the effect of leverage on earnings persistence, and 4) managerial ownership is not able to moderate effect of firm size on earnings persistence.

\section{B. Suggestion}

Based on the results of the research and discussion, as well as the conclusions above, there are some suggestions for further research as follows:

1) Future research is expected to expand the research period of time obtaining more reliable results, because in this study only a period of four years was used.

2) Future research is expected to use research samples from all manufacturing companies listed on the Indonesia Stock Exchange, because the sample in this study does not include all manufacturing companies listed on the Indonesia Stock Exchange.

3) Further research is expected to add other variables can affect earnings persistence such as company age, company performance and other supporting variables, because the influence of independent variables on the dependent variable in this study is very small, the adjusted $\mathrm{R}$ square value shows only $6.5 \%$.

4) Future research is expected to use other moderating variables to determine factors that can strengthen or weaken the effect of leverage and firm size on earnings persistence, because in this study managerial ownership variables were not able to moderate the effect of leverage and firm size on earnings persistence.

\section{REFERENCES}

[1] Amilin. Analisis Informasi Keuangan. Universitas Terbuka, 2019, pp. 5.24.

[2] Penman, S. "On Comparing Cash Flow and Accrual Accounting Models for Use in Equity Valuation," Contemporary Accounting Research (CAR), 18(8), pp. 1-21, August 2001.

[3] Putri, A. A. A. G. \& Supadmi, N. L. "Pengaruh Tingkat Hutang dan Kepemilikan Manajerial terhadap Persistensi Laba pada Perusahaan Manufaktur", E-Jurnal Akuntansi, Vol. 15, No. 2 , pp. 915-942, Mei 2016.

[4] Sulastri, D. A. "Pengaruh Volatilitas Arus Kas, Volatilitas Penjualan, Besaran Akrual dan Tingkat Hutang terhadap Persistensi Laba", Jurnal Akuntansi, Vol. 2, No. 2, pp. 1-27, Mar 2014. 
[5] Tambunan, A. L., "Analisis Pengaruh Financial Leverage , Ukuran Perusahaan, Dan Struktur Kepemilikan", JKAP: Akuntansi, Keuangan Dan Pajak, Vol. 4, No. 1, pp. 1-13, Feb 2001.

[6] Prasetyo, B., et al, "Effect of Company Value, Leverage, and Company Size on Profit Persistence in Jakarta Islamic Index (Jii) Listed Companies", International Journal of Economics, Business and Accounting Research (IJEBAR), Vol. 5, Issue. 1, pp. 128-136, March 2021.

[7] Linawati, "Pengaruh tingkat hutang, arus kas dan akrual terhadap persistensi laba dengan corporate governance sebagai variabel moderating”, Keberlanjutan : Jurnal Manajemen dan Akuntansi, Vol. 2, No. 2, pp. 678-703, Des 2017

[8] Widiatmoko, J. \& Indiarti, MG. K., "Book Tax Differences, Operating Cash Flow, Leverage and Earning Persistence in Indonesia Manufacturing Companies", Jurnal Dinamika Akuntansi, Vol. 11, No. 2, pp. 151-159, Sep 2019.

[9] Diharjo, J. P \& Loen, M., "Pengaruh book tax differences dan tingkat utang terhadap persistensi laba". Jurnal Akuntansi Dan Bisnis Krisnadwipayana, Vol. 7, No. 3, pp. 47-60, Sep 2020.

[10] Mahendra, M. E., \& Suardikha, I. M. S., "Pengaruh Tingkat Hutang, Fee Audit, dan Konsentrasi Pasar Pada Persistensi Laba". E-Jurnal Akuntansi, Vol. 30, No. 1, pp. 179-193, Jan 2017.

[11] Agustian, S., "Pengaruh kepemilikan manajerial, ukuran perusahaan, leverage, fee audit, arus kas, konsentrasi pasar, tingkat utang, dan box tax difference terhadap persistensi laba (Studi Kasus pada Perusahaan Property dan Real Estate yang Terdaftar di Bursa Efek Indonesia", Prisma (Platform Riset Mahasiswa Akuntansi), Vol. 1, No. 2, pp. 3847, Mar 2020.

[12] Septavita, N., "Pengaruh book tax differences, arus kas operasi, tingkat hutang, dan ukuran perusahaan terhadap persistensi laba (Studi Empiris Pada Perusahaan Manufaktur Yang Terdaftar di BEI Tahun 2011 2013)", Jurnal Online Mahasiswa, Vol. 3, No. 1, pp. 1309-1323, Feb 2016.

[13] Susilo, T. P., \& Anggraeni, B. M., “Analisis Pengaruh Volatilitas Arus Kas, Tingkat Utang, Siklus Operasi dan Ukuran Perusahaan Terhadap Persistensi Laba", Media Riset Akuntansi, Vol. 6, No. 1, pp 4-21. Feb 2016.

[14] Nuraeni, R., Mulyati, S., \& Putri, T. E., "Faktor-faktor yang mempengaruhi persistensi laba (Studi Kasus pada Perusahaan Property dan Real Estate yang Terdaftar di Bursa Efek Indonesia Tahun 20132015)", Accruals (Accounting Research Journal of Sutaatmadja), Vol. 2, No. 1, pp. 82-112. Maret 2018.

[15] Fanani, Z., "Analisi Faktor-Faktor Penentu Persistensi Laba", Jurnal Akuntansi Dan Keuangan Indonesia, Vol. 7, No. 1, pp. 109-123, Juni 2010 .

[16] Gunawan, A. S., Icih, I., \& Putri, T. E., "Determinants of Earning Persistence", ACCRUALS (Accounting Research Journal of Sutaatmadja), Vol. 4, No. 1, pp. 104-119, Mar 2020.

[17] Maqfiroh, C. S., \& Kusmuriyanto, "The Influence of Book Tax Differences, Operating Cash Flow, Leverage, and Firm Size towards Earnings Persistence", Accounting Analysis Journal, Vol. 7, No. 3, pp 151-158, Nov 2018.

[18] Nurochman, A., \& Solikhah, B., "Pengaruh good corporate governance, tingkat hutang dan ukuran perusahaan terhadap persistensi laba", Accounting Analysis Journal, Vol. 4, No. 4, pp. 1-9, Nov 2015.

[19] Hidayat, I., \& Fauziyah, S., "Pengaruh book tax differences, arus kas operasi, tingkat hutang dan ukuran perusahaan terhadap persistensi laba (Pada perusahaan sub sektor basic dan chemical yang terdaftar di Bursa Efek Indonesia periode 2014-2018)", CPMPETITIVE Jurnal Akuntansi Dan Keuangan, Vol. 4, No. 1, pp. 66-79, Jan 2020.

[20] Nuraini, M., \& Purwanto, A, "Analisis Faktor-Faktor Penentu Persistensi Laba", Diponegoro Journal of Accounting, Vol. 3, No. 3, pp. 606-618, Aug 2014.

[21] Arisandi, N. N. D., \& Astika, I. B. P., "Pengaruh Tingkat Utang, Ukuran Perusahaan dan Kepemilikan Manajerial pada Persistensi Laba", E-Jurnal Akuntansi Universitas Udayana, Vol. 26, No. 3, pp. 1854-1884, Mar 2019.

[22] Maulita, D., \& Framita, D. S., "Pengaruh pajak tangguhan dan ukuran perusahaan terhadap persistensi laba (The effect of deffered tax and company size on earnings persistence)", Jurnal Akuntansi, Keuangan, dan Manajemen (Jakman), Vol. 2, No. 2, pp. 141-152. Mar 2021.

[23] Pernamasari, R., "The Effect of Accrual Earnings, Corporate Governance, and Firm Size on Earnings Persistence of 100 Compass Index Companies Listedn 2015-2016", Journal of Economics and Sustainable Development, Vol. 9, No.10, pp. 196-205, July 2018.

[24] Sarah, V., Jibrail, A., \& Martadinata, S., "Pengaruh Arus Kas Kegiatan Operasi, Siklus Operasi, Ukuran Perusahaan Dan Tingkat Hutang Terhadap Persistensi Laba (Studi Empiris Pada Perusahaan Jasa Sub Sektor Konstruksi Dan Bangunan Yang Terdaftar Di Bursa Efek
Indonesia Periode 2013-2016", Jurnal Tambora, Vol. 3, No. 1, pp. 4554, Feb 2019.

[25] Jensen, M. C., \& Meckling, W. H., "Theory of the firm : managerial behavior, agency costs and ownership structure", Journal of Financial Economics, Vol. 3, pp. 305-360, July 1976.

[26] Tertius, M. A., \& Christiawan, Y. J, "Pengaruh Good Corporate Governance terhadap Kinerja Perusahaan pada Sektor Keuangan", Business Accounting Review, Vol. 3, No. 1, pp. 223-232, Jan 2015.

[27] Godfrey, Jayne et al., Accounting Theory, Seventh Edition, John Wiley, Sons Australia Ltd, 2010, pp. 376.

[28] Fadilah, N., \& Wijayanti, P., "Book Tax Differences dan Persistensi Laba Pada Perusahaan Manufaktur", Jurnal Akuntansi Multiparadigma (JAMAL), Vol. 8, No. 2, pp. 227-429, Aug 2017.

[29] Penman, Stephen H., \& Xiao-Jun Zhang, "Accounting Conservatism, the Quality of Earnings, and Stock Returns", The Accounting Review, Vol. 77, No. 2. pp. 237-64. April 2002.

[30] Koh, Y., \& Lee, H. A., "The effect of financial factors on firms' financial and tax reporting decisions", Asian Review of Accounting, Vol. 23, No. 2, pp. 110-138, July 2015.

[31] Kusuma, B., \& Sadjiarto, R., "Analisa Pengaruh Volatilitas Arus Kas, Volatilitas Penjualan, Tingkat Hutang, Book Tax Gap, dan Tata Kelola Perusahaan Terhadap Persistensi Laba", Tax \& Accounting Review, Vol. 4, No. 1, pp. 1-8, 2014.

[32] Barus, A. C., \& Rica, V., "Analisis Faktor-Faktor Yang Mempengaruhi Kualitas Laba Pada Perusahaan Manufaktur Di Bursa Efek Indonesia Tahun", Jurnal Wira Ekonomi Mikroskil, Vol. 4. No. 2, pp. 71-80, Juli 2010 .

[33] Jumiati, F., \& Ratnadi, N. M. D., "Pengaruh Kepemilikan Manajerial dan Boox Tex Differences pada Persistensi Laba", E-Jurnal Akuntansi Universitas Udayana, Vol. 8, No. 2, pp. 91-101, Agus 2014.

[34] Martani, D. \& Persada, A. E., "Analisis Faktor yang Mempengaruhi Book Tax Gap dan Pengaruhnya terhadap Persistensi Laba", Jurnal Akuntansi dan Keuangan Indonesia, Vol. 7, No.2, Des 2010.

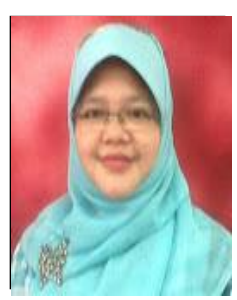

Dade Nurdiniah obtained a bachelor's degree from the Indonesian School of Economics, majoring in Accounting. She earned a Masters in Accounting (M.Ak.) from the University of Indonesia. Currently as a lecturer at Bina Insani University, West Java, Indonesia.

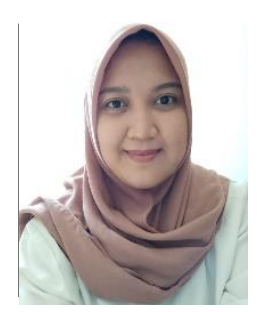

Chita Oktapriana obtained a bachelor's degree from President University, majoring in Accounting. She earned a Masters in Accounting (M.Ak.) from the Mercu Buana University. Currently as an Accounting lecturer at Bina Insani University, West Java, Indonesia.

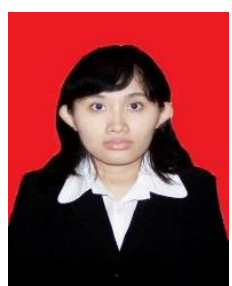

Iren Meita was born in Jakarta, she studied at the Catholic University of Atmajaya, majoring in Accounting, and specializing in Taxation. Master's education and the Accounting Profession are taken at the University of Indonesia. Currently as a lecturer at Bina Insani University, Bekasi, teaching basic accounting and taxation.

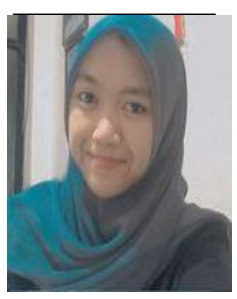

Milla Damay Yanti currently is a student of the Bachelor of Accounting Study Program, Faculty of Business, Bina Insani University. 